\title{
PELAYANAN PUBLIK DI KANTOR IMIGRASI BLITAR
}

\author{
Public Service In Blitar Immigration Office
}

\author{
Rizki Fajar Ernanda ${ }^{1}$ \\ ${ }^{1}$ Magister Ilmu Administrasi Universitas Kadiri
}

\begin{abstract}
Abstrak
Tujuan dari penelitian ini untuk mendeskripsikan dan menganalisis Pelayanan Publik di kantor Imigrasi Blitar serta faktor yang mendukung dan menghambat pelayanan publik di Kantor Imigrasi Blitar. Untuk menjawab tujuan penelitian pada di ukur melalui Kualitas Hasil Pelayanan, Kecermatan dalam Pelayanan, Ketepatan Waktu dalam pelayanan, Kesopanan dan Keramahan Pegawai dalam Pelayanan serta Keadilan dalam Pelayanan. Penelitian ini berjenis diskriptif kualitatif, dengan lokasi penelitian pada Kantor Imigrasi Blitar. Data primer berasal dari wawancara dengan 5 orang informan terpilih dan juga dari pengamatan langsung di lokasi penelitian. Sedangkan data sekunder berasal dari informasi atau data yang dimiliki oleh instansi. Penarikan kesimpulan berdasarkan data yang diolah dengan menggunakan analisis model interaktif. Dari hasil penelitian dapat disimpulkan pelayanan publik di Kantor Imigrasi Blitar termasuk baik namun belum optimal. Kualitas hasil pelayanan publik telah dilakukan sesuai dengan prosedur dan penuh kecermatan sehingga minim kesalahan; Ketepatan waktu penyelesaian pelayanan publik telah sesuai dengan peraturan yaitu maksimal 4 hari kerja; Pelayanan oleh petugas dilakukan dengan sopan dan penuh keramahan Keadilan dalam pelayanan dilakukan melalui metode antrian sehingga tidak menimbulkan konflik diantara pemohon dan lebih memberi kepastian; Keadilan dalam Pelayanan sudah dilakukan dengan metode antrian sehingga tidak menimbulkan konflik diantara pemohon. Adapun faktor yang mendukung pelayanan publik di kantor Imigrasi Blitar adalah terserdianya sarana dan prasarana yang cukup memadai, sedangkan faktor penghambatnya adalah kurangnya jumlah pegawai serta permasalahan jaringan.
\end{abstract}

Kata kunci: Pelayanan publik; kualitas hasil pelayanan; kecermatan; Profesionalitas; sarana dan prasaranan

\begin{abstract}
The purpose of this study was to describe and analyze Public Services at the Blitar Immigration office as well as factors that support and inhibit public services at the Blitar Immigration Office. To answer the research objectives in measuring through the Quality of Service Outcomes, Accuracy in Service, Timeliness in Service, Courtesy and Employee Friendliness in Service and Justice in Service This research is a qualitative descriptive type, with the location of the study at the Blitar Immigration Office. Primary data came from interviews with five selected informants and also from direct observations at the study site. While secondary data comes from information or data owned by agencies. Withdrawal of conclusions based on data processed using interactive model analysis. From the results of the study, it can be concluded that public services at the Blitar Immigration Office are good but not optimal. The quality of the effects of public services has been carried out in accordance with procedures and full of accuracy so that there are minimal errors; Timeliness of the completion of public services in accordance with the regulation, which is a maximum of 4 working days; Service by officers is carried out politely and full of hospitality Justice in service is carried out through queuing methods so that it does not cause conflict between the applicant and gives more certainty; Justice in Service has been carried out using the queue method so that it does not create conflict between applicants. The factors that support public services at the Blitar Immigration office are the availability of adequate facilities and infrastructure, while the inhibiting factors are the lack of staff and network problems.
\end{abstract}

Keywords: public service; quality of service; accuracy; professionalism; facilities and infrastructure 


\section{A.}

\section{PENDAHULUAN}

Salah satu kewajiban pemerintah adalah menyelenggarakan pelayanan untuk mewujudkan kesejahteraan masyarakat. Birokrasi merupakan instrumen pemerintah yang diharapkan mampu mewujudkan pelayanan publik tersebut secara yang efisien, efektif, berkeadilan, transparan dan akuntabel. Untuk mampu melaksanakan fungsi pemerintah dengan baik maka organisasi birokrasi harus memiliki aparatur yang profesional, tanggap, aspiratif terhadap berbagai tuntutan akan kebutuhan masyarakat.

Peran aparatur negara (birokrasi) sejak beberapa dekade yang lalu lebih mengarah kepada fungsinya sebagai abdi negara daripada fungsi sebagai abdi masyarakat. Pelayanan lebih berakses ke kekuasaan birokrasi ketimbang melayani masyarakat. Akibatnya aparatur cenderung melayani dirinya sendiri dan meminta layanan dari masyarakat (Thoha, 1993). Ini artinya pelayanan publik selama ini masih menunjukkan mental model birokrat sebagai yang dilayani oleh masyarakat, bukan justru sebaliknya aparat yang harus melayani masyarakat. Kekuasaan birokrasi sangat kuat sekali dan bahkan tak ada organisasi sosial kemasyarakatan yang mampu mengontrolnya sehingga praktek penyelenggaraan pelayanan publik selama ini yang menjadi beban masyarakat dan birokrat cenderung melakukan praktek korupsi, kolusi dan nepotisme (Mohammad, 1999).

Kenyataan ini menunjukkan bahwa selama ini pelayanan kepada masyarakat tidak menjadi prioritas pemerintah, dan ini memunculkan benih-benih ketidakpuasan terhadap pemerintah. Seiring dengan kehidupan politik dan ekonomi yang tidak menunjukkan kemajuan, maka dapat dirasakan betapa masyarakat akhirnya menjadi apriori terhadap pemerintah. Kondisi inilah yang disinyalir menjadi salah satu variabel yang mendorong munculnya berbagai macam krisis yang melanda Indonesia. Bahkan jika dikaji lebih luas, bentuk protes dan demonstrasi yang dilakukan masyarakat merupakan salah satu akibat atas kekecewaan masyarakat terhadap pelayanan publik di pemerintahan.

Berdasarkan identifikasi masalah tersebut, maka masalah dalam penelitian ini dapat dirumuskan sebagai berikut : (1) Bagaimanakah pelayanan publik di Kantor Imigrasi Blitar?

\section{B. LANDASAN TEORITIS}

\subsection{Pengertian Pelayanan}

Pelayanan adalah proses pemenuhan kebutuhan melalui aktivitas orang lain secara langsung. Pelayanan yang diperlukan manusia pada dasarnya ada 2 jenis yaitu layanan fisik yang sifatnya pribadi sebagai manusia dan layanan administratif yang diberikan oleh orang lain selaku anggota organisasi, baik itu organisasi massa maupun Negara (Moenir,1992:17).

Pelayanan adalah suatu bentuk kegiatan pelayanan yang dilaksanakan oleh instansi pemerintah baik dipusat, didaerah, Badan Usaha Milik Negara, BUMN, dan Badan Usaha Milik Daerah dalam bentuk barang maupun jasa dalam rangka pemenuhan kebutuhan masyarakat dan diatur sesuai peraturan perundang-undangan yang berlaku (Kepmenpan No. 63 tahun 2003).

Pemberian pelayanan kepada masyarakat merupakan perwujudan dari fungsi aparatur negara sebagai abdi masyarakat dan abdi negara, dan siap melayani masyarakat sesuai yang diharapkan, yaitu lancar aman dan nyaman.

Menurut Tulus (1992:23), yang didambakan masyarakat dalam pelayanan adalah : (a) Adanya kemudahan dalam pengurusan kepentingan dengan pelayanan yang cepat dalam arti tanpa hambatan yang kadang-kadang dibuatbuat; (b) Pelayanan secara wajar, tanpa gerutu sendirian atau untaian kata lain semacam yang nadanya mengarah pada permintaan tertentu baik dengan alas an untuk dinas atau kesejahteraan; (c) Perlakuan pelayanan yang sama dalam kepentingan yang sama, tertib dan tidak pandang bulu; (d) Pelayanan yang jujur dan terus terang, artinya apabila ada hambatan karena suatu masalah yang tidak dapat dielakkan hendaknya diberitahukan sehingga orang tidak menunggu sesuatu yang tidak menentu.

Menurut pedoman umum penyelenggaraan pelayanan publik di lingkungan organisasi publik diatur oleh Keputusan Menteri Pendayagunaan Aparatur Negara No: 63/KEP/M.PAN/7/2003 harus mengutamakan prinsip - prinsp pelayanan sebagai berikut: (1) Kesederhanaan, dalam arti bahwa prosedur/tata cara pelayanan diselenggarakan secara mudah, lancar, cepat, tidak berbelit-belit, mudah dipahami dan mudah dilaksanakan.

(2) Kejelasan kepastian, dalam arti adanya kejelasan dan kepastian mengenai : (a) Prosedur/ tata cara pelayanan umum; (b) Persyaratan pelayanan umum, baik teknis maupun administratif; (c) Unit kerja dan atau pejabat yang berwenang dan bertanggung jawab dalam memberikan pelayanan umum; (d) Rincian biaya / tarif pelayanan umum dan tata cara pembayarannya; (e) Jadual waktu penyelesaian pelayanan umum;

\subsection{Pelayanan Prima}

Pelayanan prima merupakan salah satu bentuk pelayanan kepada publik atau masyarakat 
yang mengacu pada kepuasan pelanggan. Pengertian pelanggan secara maksimal terhadap instansi pemerintah yang memberikan pelayanan. Jika pelayanan prima berorientansi pada kepuasan pelanggan, maka kepuasan dimaksud adalah tingkat perasaan seseorang setelah membandingkan kinerja (hasil) yang dirasakan dengan harapannya. Karena itu, maka tingkat kepuasaan adalah fungsi dari perbedaan antara kinerja yang dirasakan dengan harapan. Dengan demikian pelanggan dapat merasakan hal-hal sebagai berikut : (a) Kalau pelayanan di bawah harapan, pelanggan akan merasa kecewa; (b) Kalau pelayanan sesuai harapan, pelanggan akan merasa puas; (c) Kalau pelayanan melebihi harapan, pelanggan akan sangat puas, senang dan atau gembira (Sugiyanti, 1999: 40).

Uraian di atas meunjukkan perlunya kinerja pemberi jasa dalam memberikan layanan hendaknya dapat mengikuti keinginan pelanggan, dan yang terpenting bagi pemberi jasa adalah bagaimana caranya pelanggan merasa puas atas layanan yang diberikan. Oleh sebab itu untuk menjamin kepuasan pelanggan perlunya menampilkan keprimaan dalam memberikan layanan, dan hal tersebut dapat dilakukan dengan mempertimbangkan aspek-aspek sebagai berikut: (a) Kepuasan total pelanggan; (b) Menjadikan kualitas sebagai tujuan utama dalam pelayanan;

(c) Membangun kualitas dalam sebuah proses;

(d) Menerapkan filosofi, berbicara berdasarkan fakta; (e) Menjalin kemitraan, baik internal maupun eksternal. (Sugiyanti, 1999 : 35).

Kepuasan pelanggan merupakan tujuan utama dalam pelayanan prima, namun hal tersebut dapat dengan memperhatikan apa yang menjadi keinginan pelanggan. Oleh karena itu setiap aparatur pelaksana harus menunjukkan kinerja yang baik dalam rangka mencapai kepuasan pelanggan, karena kepuasan pelanggan dapat dicapai apabila para pelaksana dapat memahami keinginan pelanggan. Sebagaimana dikemukakan Sugiyanti (1999 : 34) bahwa faktor manusia dalam memberikan layanan sangat berpengaruh terhadap kepuasan total pelanggan.

\subsection{Kepuasan Masyarakat}

Kepuasan pelanggan dapat tercapai apabila kebutuhan, keinginan dan harapan pelanggan terpenuhi, karena itu, Tjiptono (1997:129) menyatakan bahwa sedikitnya terdapat tiga level harapan pelanggan mengenai kualitas : (a) Harapan pelanggan yang paling sederhana dan berbentuk asumsi must have, atau tidak take it for granted. Misalnya : (i) saya berharap perusahaan penerbangan menerbangkan saya sampai tujuan dengan selamat, atau (ii) saya berharap Bank dapat menyimpan uang saya dengan aman dan menangani saldo rekening saya dengan benar. (b) Pada level kedua ini, kepuasan pelanggan dicerminkan dalam pemenuhan persyaratan dan atau spesifikasi. Misalnya : (i) saya berharap dilayani dengan ramah oleh pegawai perusahaan penerbangan, (ii) saya pergi ke Bank, dan tellernya ternyata sangat ramah, informative dan suka menolong transaksitransaksi saya. (c) Pada level ketiga ini pelanggan menuntut suatu kesenangan (delightfulness) atau jasa yang begitu bagusnya sehingga membuat saya tertarik. Misalnya : perusahaan penerbangan itu memberi semua penumpang makanan yang sama dengan yang khusus diberikan kepada penumpang kelas satu oleh perusahaan penerbangan lainnya.

Menurut Osborne, 1992 : 208-212) sebagai organisasi yang menjual jasa, yang berorientasi pada kepuasan pelanggan hendaknya memperhatikan hal-hal sebagai berikut : Memaksa pemberi jasa untuk dapat bertanggung jawab kepada pelanggannya; (b) Mendepolitisasi keputusan terhadap pilihan pemberi jasa; (c) Merangsang lebih banyak inovasi; (d) Memberi kesempatan kepada orang untuk memilih diantara berbagai macam pelayanan; (e) Pemborosan lebih sedikit karena pemasokan disesuaikan dengan permintaan. (f) Mendorong pelanggan untuk membuat pilihan dan mendorong untuk menjadi pelanggan yang berkomitmen.

Dengan demikian untuk tercapainya layanan seperti yang diharapkan masyarakat, maka sebagai penjual jasa harus peka terhadap kemauan dan kepentingan pelanggan.

\section{METODE PENELITIAN}

Penelitian yang dilakukan penulis termasuk penelitian diskriptif kualitatif. Penelitian deskriptif dimaksud adalah mendeskripsikan fenomena yang terjadi dalam kaitannya dengan pelayanan publik di Kantor Imigrasi Blitar kepada masyarakat. Dengan pendekatan ini peneliti dapat mengevaluasi mengenai kinerja aparatur, terutama kesiapan yang dilakukan lembaga tersebut dalam memberikan layanan. Melalui pendekatan diskriptif, peneliti akan memperoleh pemahaman yang mendalam (insight) dan menyeluruh (whole) terhadap fenomena yang terjadi, terutama yang berkenaan dengan kinerja aparatur dalam memberikan layanan pada masyarakat.

Dengan menggunakan penelitian deskriptif kualitatif, maka peneliti akan dapat mengevaluasi mengenai aktivitas yang dilakukan aparatur di Kantor Imigrasi Blitar dalam memberikan layanan pada masyarakat. 


\section{PEMBAHASAN}

\subsection{Pelayanan Publik di Kantor Imigrasi Blitar}

Kualitas Hasil Pelayanan yang dihasilkan. Pelayanan yang tepat diartikan sebagai pemberian pelayanan atau melayani keperluan orang atau masyarakat sesuai dengan aturan pokok dan tata cara yang telah ditetapkan. Ketepatan pelayanan akan diperoleh jika dilaksanakan sesuai kualifikasi yang diharapkan, baik ditinjau dari prosedur, ketelitian, dan kecermatan, maka akan dicapai atau dihasilkan layanan yang berkualitas.

Dari hasil wawancara beberapa informan, dalam Kualitas Hasil Pelayanan yang dihasilkan, pegawai dinilai secara konsisten telah bekerja mengikuti prosedur dalam pelayanan. Hal tersebut dirasakan telah sesuai oleh para pemohon paspor di Kantor Imigrasi Blitar. Namun demikian, pemohon masih merasakan adanya prosedur yang dirasakan cukup panjang, sehingga membutuhkan waktu yang cukup lama untuk menyelesaikan tahapan tersebut, apalagi ditambah dengan antrian yang cukup banyak.

\section{a. Kecermatan dalam pelayanan}

Kecermatan sangat diperlukan dalam pelayanan kepada masyarakat supaya pelayanan yang diberikan tidak mengalami kesalahan yang justru akan menyebabkan pengulangan kembali pekerjaan dan merugikan masyarakat dari segi waktu, tenaga dan biaya. Dengan kecermatan pegawai yang optimal diharapkan hasil kerjanya dapat dirasakan oleh masyarakat sebagai pemohon.

Selain itu, dari pantauan penulis di lokasi penelitian, hal yang mendukung kecermatan pegawai bekerja adalah faktor pengalaman di bidang pelayanan publik karena merupakan kegiatan rutin di Kantor Imigrasi Blitar. Dengan dimilikinya pengalaman kerja, akan lebih memahami pekerjaan tersebut sehingga semakin minim dari kesalahan.

Memperhatikan pendapat-pendapat para informan serta hasil observasi penulis, maka dapat dikatakan pegawai cukup cermat dalam membuat paspor, meskipun diakui masih terdapat kesalahan namun jumlahnya sangat sedikit dan jarang sekali. Dengan demikian secara keseluruhan dapat dikatakan pegawai cukup cermat dalam bekerja.

Dari hasil penelitian pada kedua indikator ketepatan kerja di atas maka dapat dikatakan bahwa pelayanan publik di Kantor Imigrasi Blitar dalam pelayanan pembuatan paspor telah menghasilkan paspor dengan sangat minim kesalahan karena dilakukan sesuai prosedur, teliti dan cermat.

\section{b. Ketepatan waktu dalam pelayanan}

Pelayanan yang baik adalah pelayanan yang memberi kepastian waktu kepada masyarakat, sehingga masyarakat tidak menghabiskan waktu terlalu lama dan menunggu tanpa kejelasan penyelesaiannya. Oleh karenanya pegawai seharusnya tidak menunda-nunda proses pelayanan jika memang seluruh berkas telah sesuai dengan persyaratan yang ditentukan.

Mengenai pelayanan publik di Kantor Imigrasi Blitar dalam pelayanan pembuatan paspor di Kantor Imigrasi Blitar, khususnya mengenai ketepatan waktu pelayanan, penulis melakukan wawancara dengan beberapa narasumber dan observasi di lokasi penelitian.

Sedangkan dari sisi pegawai, ketepatan waktu dalam pembuatan paspor diketahui dari hasil observasi penulis di lokasi penelitian dapat disampaikan bahwa, antrian pelayanan tiap harinya cukup banyak. Saat datang pertama kali, biasanya para pemohon menanyakan terlebih dahulu apa saja persyaratannya. Untuk menunggu antrian di customer service tersebut membutuhkan rata-rata 10 menit. Setelah dirasa cukup, maka biasanya pemohon mengambil formulir dan pulang.

Kemudian untuk pemohon yang telah melengkapi persyaratan, rata-rata mereka menunggu tiap 10 menit, dan masuk tahapan pelayanan pertama, yaitu penyerahan formulir. Tidak membutuhkan waktu lama untuk menyerahkan formulir ini karena telah diisi oleh pemohon. Lalu menunggu lagi dengan waktu 15 menit untuk verifikasi data. Waktu verifikasi membutuhkan rata-rata 20 menit tiap orang karena adanya sesi wawancara. Seterusnya menunggu sekitar 20 menit untuk pemotretan. Jika pemohon hendak mengambil paspor pada hari itu juga, maka harus merelakan waktu cukup lama yaitu sekitar 2 jam, karena proses pengisian dan data pada paspor dan registrasinya. Untuk tahapan ini banyak pemohon mengambil pada hari berikutnya, kecuali pemohon yang sangat memerlukan paspor hari itu juga. Kebanyakan pemohon yang rela menunggu adalah pemohon dari luar wilayah kerja Kantor Imigrasi Blitar (observasi, 28-30 Agustus 2017)

Dari hasil observasi tersebut, telah tampak bahwa pelayanan pembuatan paspor yang dilakukan oleh pegawai dari sisi waktu telah sedemikian dioptimalkan, artinya pegawai telah melakukan rutinitas pelayanan dengan waktu yang rata-rata yang efektif, sehingga penyelesaian pembuatan paspor dapat diselesaikan sesuai waktu yang telah ditetapkan. Pada umumnya pegawai telah mampu mengatur waktu dalam menyelesaikan pekerjaan sehingga menghasil pekerjaan yang sesuai dengan tepat waktu. 
Hasil penelitian mengenai ketepatan waktu pembuatan paspor di Kantor Imigrasi Blitar menggambarkan bahwa pegawai/ petugas pelayanan telah mampu menyelesaikan pembuatan paspor sesuai dengan waktu yang telah ditentukan. Hal yang ditemui sebagai persoalan yaitu lama prosesnya dikarenakan antrian yang cukup banyak, sehingga pemohon harus rela mengantri kurangnya Petugas pelayanan fasilitas yang kurang memadai serta permasalahan di kesisteman.

\section{c. Kesopanan dan keramahan pegawai dalam pelayanan}

Adalah sikap dan perilaku yang terpuji jika para petugas dalam memberikan pelayanan kepada masyarakat melakukannya dengan sopan dan ramah serta saling menghargai dan menghormati, sebab sikap tersebut menandakan pelayanan yang dilakukan dengan "hati".

Dalam segala hal yang berkaitan dengan suatu pelayanan, tentunya semua pegawainya harus sopan dalam memberikan pelayanan kepada masyarakat publik. Karena dengan adanya kesopanan yang dimiliki para pegawai itulah yang dapat membuat masyarakat merasa senang dan puas pada saat mendapatkan layanan. Pegawai Kantor Imigrasi Blitar harus mempunyai tingkah laku yang sopan, dalam artian kesopanan dalam tingkah laku tidak hanya terbatas pada tindak tanduk saja melainkan juga tegur sapa dan tutur kata di dalam melayani semua masyarakat atau pemohon yang datang ke kantor ini.

Hasil penelitian melalui pengamatan yang dilakukan oleh penulis, dapat disampaikan bahwa pegawai pelayanan tersebut telah cukup sopan dalam melakukan suatu tindakan kepada masyarakat nya yang sedang mengurus pelayanan. Sikap sopan tersebut ditampilkan dengan cara bertuturkata yang baik dan tidak tendensius. Selain itu, dalam menanya-kan sesuatu kepada pemohon, petugas mendahului pertanyaan dengan kata "maaf". (observasi, 10-14 November 2014)

Keramahan juga merupakan salah satu bagian yang terpenting di dalam kegiatan pelayanan. Semua pegawai yang berada di kantor Imigrasi Blitar tentunya harus mempunyai sikap yang ramah dan disertai tutur kata yang baik, yang merupakan salah satu bentuk wujud penghormatan untuk menghargai masyarakatnya. Selain itu, pegawai pelayanan juga harus memberikan senyum kepada masyarakat yang sedang dilayaninya. Karena senyum adalah bagian dari keramahan yang dimiliki oleh pegawai kantor Imigrasi Blitar yang harus diekspresikan kepada semua masyarakat yang datang dan sedang berurusan di kantor ini.
Berdasarkan hasil wawancara dengan beberapa informan dapat disimpulkan mengenai pelayanan publik dari sisi keramahan, sebagian besar orang mengatakan bahwa Pegawai Kantor Imigrasi bersikap cukup ramah dalam melakukan pelayanan.

\section{d. Keadilan dalam pelayanan}

Dalam hal ini yang dimaksud dalam keadilan dalam pelayanan yaitu pelayanan yang tidak membedakan golongan/status masyarakat yang dilayani. Keadilan ini sangat penting karena pada dasarnya kedudukan masyarakat dihadapan pemerintah adalah sama. Pelayanan publik akan optimal jika tidak membedakan perlakuan kepada pemohon.

Pada sub fokus ini, akan menyampaikan hasil penelitian yang menggambarkan sejauhmana pegawai di bagian pelayanan memiliki kemampuan untuk menciptakan rasa keadilan bagi masyarakat yang dilayaninya. Mengenai keadilan dalam pelayanan yang diberikan pegawai Kantor Imigrasi Blitar dalam melayani pemohon dalam pembuatan paspor diketahui dari hasil wawancara dengan beberapa informan.

Dari hasil wawancara dari beberapa sumber baik dalam organisasi maupun anggota masyarakat sebagai pemohon dapat dikatakan bahwa pegawai telah cukup memberi rasa adil dalam mengatur pemberian layanan pembuatan paspor di Kantor Imigrasi Blitar antara lain melalui metode antrian walaupun memang ada beberapa yang diprioritaskan untuk keadilan.

\section{E. KESIMPULAN DAN REKOMENDASI 5.1. Kesimpulan}

Kualitas kerja adalah mutu yang dihasilkan dari pekerjaan seseorang. Lingkungan kerja pemerintahan, sarat akan pelaksanaan birokrasi, aturan dan pedoman kerja yang telah ditetapkan, oleh karenanya tolok ukur dari kualitas kerja yang utama dalam pemerintahan adalah apakah pekerjaan yang dilakukan telah sesuai dengan peraturan dan prosedur kerja. Hal lainnya adalah kecermatan pegawai.

Hasil penelitian di lapangan menunjukkan bahwa paspor yang dikeluarkan Kantor Imigrasi Blitar yang berkualitas dalam arti paspor yang minim kesalahan. Sangat jarangnya mendapat komplain dari pemohon merupakan salah satu indikator dari hasil pekerjaan yang berkualitas. Selain itu hasil tersebut menunjukkan bahwa pegawai telah melakukan pekerjaan dengan penuh kecermatan.

berkenaan dengan waktu dalam pembuatan paspor. Menurut peraturan, paspor selesai (dapat diambil) maksimal 4 hari kerja. Hasil penelitian menunjukkan bahwa pada 
umumnya pegawai berhasil menyelesaikan pembuatan paspor sesuai dengan target penyelesaian bahkan ada yang sehari selesai.

Penyelesaian pekerjaan sesuai dengan waktu sangat penting dalam pelayanan pembuatan paspor. Oleh karenanya pegawai perlu memahami proses penyelesaian pekerjaannya. Kebiasaan pegawai yang tidak memperhatikan waktu akan membawa karakter pegawai yang santai, kurang inovatif dan kreativitas dan cenderung kurang bertanggung jawab. Pemanfaatan waktu kerja yang seefektif mungkin akan memaksimalkan hasil kerja pegawai. Hal yang ditemui sebagai persoalan waktu ini yaitu lama prosesnya dikarenakan antrian yang cukup banyak, sehingga pemohon harus rela mengantrinya. Pada sub fokus kesopanan dan keramahan pegawai dalam Pelayanan, berdasarkan hasil penelitian, sebagian informan pemohon mengatakan bahwa Pegawai Kantor Imigrasi bersikap sopan dan cukup ramah dalam melakukan pelayanan.

Dalam melakukan pelayanan kepada masyarakat, perlu diperhatikan bagaimana cara bersikap, karena pelayanan yang prima adalah pelayanan yang memberi kepuasan, menyenangkan dan tidak menyusahkan. Yang perlu diperhatikan adalah bahwa pihak yang dilayani adalah anggota masyarakat merupakan manusia yang mempunyai perasaan. Perasaan itu berupa perasaan ingin diperhatikan, mendapatkan kepuasan dan ingin dilayani dengan baik. Oleh karenanya sikap pegawai dalam melayani masyarakat perlu mendapat penekanan karena paradigma masa lalu telah menggambarkan sikap birokrasi yang berorientasi pada dirinya sendiri, kurang melayani masyarakat dengan sepenuh hati sudah berlaku lagi pada saat ini.

Pada sub fokus berikutnya adalah adanya keadilan dalam pelayanan. Pelayanan yang adil adalah pelayanan yang tidak membedakan. Dari hasil wawancara dari beberapa sumber baik dalam organisasi maupun anggota masyarakat sebagai pemohon dapat dikatakan bahwa pegawai telah cukup memberi rasa adil dalam mengatur pemberian layanan pembuatan paspor di Kantor Imigrasi Blitar antara lain melalui metode antrian.

Berdasarkan hasil pembahasan pada bab terdahulu, maka kesimpulan yang dapat diambil peneliti adalah :

Pelayanan Publik di Kantor Imigrasi Blitar sudah baik namun belum maksimal, Hal tersebut berdasarkan pada : (a) Kualitas hasil pelayanan publik di kantor Imigrasi Blitar telah dilakukan sesuai dengan prosedur; (b) Kecermatan dalam Pelayanan publik telah dirasa baik, tidak adanya kesalahan pemeriksaan karena semua disesuaikan dengan peraturan yang telah ditetapkan; (c) Pelayanan publik yang dilakukan oleh petugas di Kantor Imigrasi Blitar telah dilakukan dengan sopan dan penuh keramahan;

Keadilan dalam pelayanan dilakukan melalui metode antrian sehingga tidak menimbulkan konflik diantara pemohon dan lebih memberi kepastian dan keadilan

Faktor-Faktor yang Mendukung Pelayanan Publik di Kantor Imigrasi Blitar

Faktor - faktor yang mendukung Pelayanan Publik di Kantor Imigrasi Blitar adalah Sarana dan Prasarana yang telah Lengkap, dari Ruang Tunggu yang luas dan nyaman karena dilengkapi dengan dua buah Air Conditioner, Dispenser Air Dingin, Booth Charger untuk Handphone, Ruang Menyusui serta Ruang Bermain untuk Anak, sampai dengan Kantin, Mushola, Parkiran yang luas serta Toilet yang nyaman dan Bersih.

Faktor-Faktor yang Menghambat atau Menjadi Kendala dalam pelayanan publik di Kantor Imigrasi Blitar

Dari hasil penelitian mengenai efektifitas kerja menunjukkan hasil kurang optimal. Hal ini dikarenakan jumlah petugas dengan beban pekerjaan tidak seimbang. Jumlah petugas sedikit sedangkan beban pekerjaan sangat banyak, dalam artian bahwa jumlah petugas kurang mampu mencover seluruh pekerjaan. Teridentifikasi pekerjaan tersebut ada pada bagian pemberkasan. Pemotretan dan sidik jari.

Meskipun peningkatan pelayanan publik seharusnya mampu dilakukan oleh pegawai karena adanya faktor pendukung yaitu dasar hukum terselenggarannya pembuatan paspor dan dukungan pimpinan namun faktor seperti kurangnya tenaga (aparatur/pegawai) dan jaringan menjadi faktor yang menghambat optimalisasi pelayanan publik. Dengan demikian dapat disimpulkan bahwa pelayanan publik di Kantor Imigrasi Blitar adalah Baik.

Kurang optimalnya pelayanan publik di Kantor Imigrasi Blitar disebabkan oleh terbatasnya aparatur yang profesional, permasalahan jaringan serta sarana operasional yang belum memenuhi kualifikasi yang dibutuhkan. Keadaan pegawai secara kualitas kurang memadai sehingga pelayanan publik secara akumulatif belum sesuai yang diharapkan.

\subsection{Rekomendasi}

Sesuai dengan hasil penelitian dan kesimpulan yang telah penulis kemukakan, maka penulis dapat memberikan saran-saran sebagai berikut: (1) Hendaknya prosedur dan tahapan dalam pelayanan publik lebih dapat disederhanakan sehingga pemohon dapat lebih 
mudah mendapatkan produk dari pelayanan publik. (2) Hendaknya pihak pimpinan mengecek kembali mengenai kelayakan jaringan / sistim pada pelayanan publik sehingga dapat dipastikan pelayanan selalu berjalan dengan optimal. (3) Hendaknya jumlah pegawai di Kantor Imigrasi dapat ditambah, terutama pegawai berstatus honorer untuk pekerjaan yang sifatnya penunjang. (4) Hendaknya menambahkan Booth / Konter-konter pelayanan sehingga hasil yang didapat dapat menunjang pelayanan Publik di Kantor Imigrasi Blitar.

\section{F. REFERENSI}

Davis, Keith dan Newstron, Jhon W. 2000, Perilaku Dalam Organisasi. Jilid Kedua. Edisi ketujuh. Erlangga, Jakarta.

Flippo, Edwin. P. 2001, Manajemen Pesonalia dan Sumber Daya Manusia. Edisi keenam, Erlangga, Jakarta.

Gomes, Faustino Cardoso. 2006, Manajemen Sumber Daya Manusia, Penerbit Andi, Yogyakarta.

Herbowo, Setyo.2002. Penelitian Terdahulu. Kinerja Pelayanan Publik Dinas Kependudukan dan Catatan Sipil Kabupaten Sragen - Sragen.

Indrawanto. 2001, Teori Administrasi Publik dan Birokrasi Perspektip Transendental, Taroda, Malang.

Keban, T. Yeremias. 2004, Enam Dimensi Strategi Administrasi Publik Konsep, Teori dan Isu, Gava Media, Yogyakarta.

Kumorotomo, Wahyudi., 2006 Akuntabilitas Birokrasi Publik. Pustaka Pelajar, Yogyakarta.

Mangkunegara, A.A. Anwar Prabu. 2002 Manajemen Sumber Daya Manusia -. Reflika Aditama - Jakarta.

Miles, Matthew B. dan A Michel Huberman. 2002 Analisis Data Kualitatif. Cetakan I. UI Press. Jakarta.

Mohamad, Ismael. 2005, Kualitas Pelayanan Masyarakat: Konsep dan Implementasinya, Dalam Miftah Thoha (editors) Administrasi Negara, Demokrasi dan Masyrakat Madani. Jakarta : Lembaga Administrasi Negara.
Moleong, Lexy, j. 2005, Metodologi Penelitian Kualitatif, PT. Remaja Rosdakarya, Bandung.

Pasolong, Harbani. 2010, Teori Administrasi Publik, Alfabeta, Bandung.

Sedarmayanti. 2001, Sumber Daya Manusia dan Produktivitas Kerja, Mandar Maju, Jakarta.

Siagian, S. P.. 2003, Teori dan Praktek Kepemimpinan (cetakan kelima), Rineka Cipta, Bandung.

Simamora, Henry. 2004, Manajemen Sumber Daya Manusia, STIE YKPN, Yogyakarta.

Sondang P. Siagian. 2009, Kiat Meningkatkan Produktivitas Kerja, PT. Rineka Cipta, Jakarta.

Sugiarti, 2006. Penelitian Terdahulu. Studi Evaluasi Kinerja Aparatur dalam Pelayanan Publik di Dinas Pekerjaan Umum Kabupaten Tulungagung - Tulungagung.

Tika, P. (2006) Budaya Organisasi Dan Peningkatan Kinerja Perusahaan PT. Bumi Aksara. Jakarta.

Veithzal, Rivai. 2005, Manajemen Sumber Daya Manusia, Raja Grafindo Persada, Jakarta.

Zauhar, Soesilo. 2005, Birokrasi, Birokratisasi dan Post Bureaucracy. Unibraw, Malang.

Undang - Undang Nomor 6 Tahun 2011 tentang Keimigrasian

Undang - undang Nomor 32 Tahun 2004 tentang Pemerintahan Daerah. Lima Bintang. Surabaya.

Peraturan Pemerintah Nomor 31 Tahun 2013 tentang Peraturan Pelaksanaan UndangUndang Nomor 6 tahun 2011 tentang Keimigrasian

Surat Keputusan Menteri Kehakiman dan HAM RI No. 05-PR.07.04 Tahun 2002 tanggal 29 September 2002 tentang Pembentukan Kantor Imigrasi Kelas II Blitar.

Instruksi Presiden Nomor 1 Tahun 1995 tentang Perbaikan dan Peningkatan Mutu Pelayanan oleh Aparatur Negara Kepada Masyarakat. Jakarta.

Keputusan Menteri Pendayagunaan Aparatur Negara nomor 63/KEP/M.PAN/7/2003 tentang Pedoman Umum Penyelenggaraan Pelayanan Publik 